\title{
Interview as Archive: Moving in Disciplinary Space from Cultural Studies to Cultural Science. An Interview with John Hartley AM.
}

\author{
SAMANTHA OWEN \\ Curtin University, Australia; email: samantha.owen@curtin.edu.au
}

Keywords: Cultural Science, cultural studies, cultural semiotics, creative industries

On 19 July 2021 John and I met at Curtin University on the unceded lands of the Noongar people to discuss his passage from cultural studies to cultural science. For a short time I was the caretaker Editor-in-Chief and so it seemed appropriate that John and I have the conversation to mark the transition of the journal to a new home and team following the long editorship by John while Cultural Science resided in the Centre for Culture and Technology (CCAT) Curtin University. Appropriately, our conversation was bookended by morning coffee and then lunch with Lucy Montgomery, the Cultural Science Commissioning Editor, leader of the Innovation in Knowledge Communication research program at CCAT and co-lead of the Curtin Open Knowledge Initiative.

I framed the discussion around John's career so far in an attempt to capture his contributions to the fields of cultural studies, creative industries, cultural science and the Humanities generally, and also to identify the complex of academics, individuals and institutions that he worked with and built up throughout his career inside the academy. John publishes prolifically, and the volume of his publications is extraordinary, as is his impact. This is clear in the way John is intellectually generous and innovative: he follows and creates trends and in the shaping of disciplines he remains focused on how to create and sustain communities of practice. What came out of the interview is that John's academic core, his driving force through his life of work remains unchanged: contributions to culture - high or low - should be taken seriously, whether that be banal everyday television, comics, Paul Smith, Welsh nationalism or the climate activism of Greta Thunberg.

Dr Samantha Owen, Faculty of Humanities, Curtin University

SO: John, where did your academic journey begin? What is a who, when, why of JH, what are your intellectual foundations?

$\mathrm{JH}$ : I started out as a student of history at Cardiff University. When I went there it had the highest percentage of working class students anywhere in the UK and I felt at home there. At Cardiff I came under the influence of Professor Terence Hawkes, an enfant terrible Shakespearian scholar and critic, and moved across to English Literature for undergraduate studies. Then in 1972 I managed to get a scholarship to study for a PhD ... so I actually began my intellectual career as a Shakespearian. What 
was different about that was that I was interested in Shakespeare's audience as well as the plays; and one of the problems with the audience is that they are all dead. So it was quite difficult to say much about them or how they reacted to the plays or what the relationship was between the actors and the audience on stage. Terry [Hawkes] was very keen to distinguish between drama as a form and British theatre at the time - high-brow, elite, clipped-accent Shakespearians perpetrating high culture on the unsuspecting masses. He saw drama as occurring much more profoundly on television. We became interested in the relationship between television and audiences as coparticipants in the drama of modernity. We were just as interested in political events such as assassinations and riots on television news as we were in drama as a fictional form.

By now it was around $1975 \ldots$ and I didn't submit my PhD. I got a job as a research assistant at the Polytechnic of Wales to help them prepare for a communication studies degree programme, which at that time was unknown. They had hired John Fiske to lead it. John was an interesting character who went on to become a global celebrity of cultural studies in America. His recent death has shown just how much he was loved and appreciated. Anyway, in the mid-1970s, John Fiske came to Wales; Terry Hawkes was editing a book series called New Accents and he asked us to do a book on television. So, instead of completing my PhD I wrote Reading Television (1978) with John Fiske. That became quite a well-known book in its own right.

Shortly after that Fiske left the Polytechnic and moved to WAIT - the Western Australian Institute of Technology [later Curtin] - in Perth. After arriving he agitated for me to get a job here too. I arrived in Australia in 1985 and took up a post at Murdoch University. When Fiske and I started in Australia we had jobs in Communication Studies, the students did media studies and we wrote cultural studies. They were all the same thing.

\section{SO: What was your relationship to the Birmingham School of Cultural Studies?}

$\mathrm{JH}$ : There were two groups in Britain which were very influential at that time.

The first one was indeed Stuart Hall's or Richard Hoggart's group at Birmingham. All of that came out of English with a literary but not theoretical background, which then met up with sociology and Marxism. These two things were very influential on both me and cultural studies in the early days. Working Papers in Cultural Studies (WPCS) was the journal associated with Birmingham.

The second were the Russian formalists and structuralist theorists in London who were working out of the Society for Education in Film and Television (SEFT) and the journals Screen and Screen Education. They were very much into the text, and French theorists like Roland Barthes, and the Russians, Tzvetan Todorov, Vladimir Propp, and various others.

So these were the big influences we paid attention to and yet we were communicating to 17-year old sandwich-course students at polytechnics. They were an energetic cohort but had no intellectual background of that kind, but they wanted jobs in the media, which was burgeoning and interesting and had both public and commercial aspects.

The other market we were communicating to were the Americans, who were intellectually hungry, and this is where John Fiske would go when he left Australia shortly after I arrived. Although there was a tradition called Rhetoric, the American discipline of Communication came very strongly out of the social sciences. They just didn't have theories of meaning or culture or representation, and so they were very interested in what was going on in cultural studies and screen studies. That's where we found our niche: talking to the Americans. 
JH: No! I did not. I got my PhD at Murdoch by writing up my contributions to television and cultural studies; and so I have a Murdoch PhD.

SO: When John Fiske came out to WAIT what did he do here?

JH: He worked in cultural studies and was associated with Graeme Turner (1990) there, and Michael O'Toole (1990) and Bob Hodge (2017) at Murdoch. Hodge, Turner and Fiske wrote Myths of Oz: Reading Australian Popular Culture (1987). He only stayed in Australia for a short time and we didn't cross paths - I arrived as he left.

SO: Tell me about Murdoch when you arrived in January 1985.

$\mathrm{JH}$ : They advertised a post and I was interviewed for it at the Association of Commonwealth Universities office in London, by Geoffrey Bolton (See: Megarrity, 2018). Murdoch was amazing. It was much more like a polytechnic. O'Toole and Hodge led the Human Communication department and the intellectual heft was also provided by literary theorist John Frow (1995) and philosopher Horst Ruthrof (1997). There were very good people in Asian Studies and quite a wide range of interests. Murdoch encouraged this, because all first year students had to enrol in one of two interdisciplinary courses. One was STAR or Structure, Thought and Reality and the other was Evolution and Change - perhaps the seed of cultural science.

SO: How was Evolution and Change the seed of cultural science?

$\mathrm{JH}$ : Evolution and Change was run out of the Murdoch Veterinary School by the then Associate Professor John Grandage (http://www.greatsouthernsciencecouncil.org.au/scientists/john-grandage) and he recruited me to contribute to that course. I ran a lecture on the 'evolution' of the mass media, and made an argument that the first mass medium wasn't television or newspapers but the medieval Catholic Church. Working in this unit made me think about the longue durée aspect of media studies, which was very neglected in media studies itself. In the unit we were asking questions about the natural world and how it works.

SO: You left Murdoch after a decade: having achieved the titles of Dr and Associate Professor. Where did you go, Edith Cowan?

JH: Yes, I went there in 1995 as the first Professor of Media. I worked under Robyn Quin (Quin, 2007). I only stayed one year as I had also applied to Cardiff and just after I started at ECU they offered me a job.

SO: So you arrived at Cardiff in 1996?

$\mathrm{JH}:$ Yes, I was hired as a research professor and arrived just after a merger of the Cardiff universities to a conglomerate department of English, of which Journalism, which I led, was a 'section'. I used the position to ask the university to launch Journalism as a separate department. In 1997 we launched Journalism, Media and Culture (JOMEC) and I thought I would stay there for the rest of my life, but I only stayed four years. 
SO: In a few years you have moved from English Literature to Media Studies and Cultural Studies, to Human Communication at Murdoch and then to Journalism ... without being a journalist.

JH: Yes, not a journalist but I started a lot of journals! - Gair Rhydd, the Cardiff university newspaper when I was a student; Literature Teaching Politics when I was with the Cardiff Critical Seminar; Cultural Studies, which was previously the Australian Journal of Cultural Studies; and in 1997 the International Journal of Cultural Studies, which had an international focus and moved beyond the class politics of the Birmingham school.

SO: Tell me more about the Cultural Studies journal.

$\mathrm{JH}:$ Well, it started at Murdoch with Michael O'Toole, Frow, Fiske and various others as a journal of Cultural Studies. It was organised around the then ascendency of semiotics, and literary theory. I published in it before I came to Australia. When I arrived they were interested in making it into an international journal. Fiske and I had had some success with Reading Television (1978) and we knew how to talk to European publishers, so we offered it to Routledge, and they took it. It became the journal Cultural Studies and the first general editor was Fiske. The original idea was that it would be run out of three continents and the general editorship would rotate - John Fiske did his, then it went to America to Lawrence Grossberg (1997) where it stayed. Routledge were very pleased with it and it did very well. It started the internationalisation of cultural studies as a discipline and stopped it from being just about British class war, which is a very important thing but it's not all there is in the world. I was on the Board of it for a while. I eventually came off it as I wanted to start my own journal. Chris Rojek, who was at Sage, was also an academic and he had strong feelings about the way in which cultural studies had become something of a cult in Britain, so he was keen to start a journal which did something different. Hence, through Sage, we started the International Journal of Cultural Studies, which was initially a very good seller.

\section{SO: So that was your contribution while at Cardiff?}

$\mathrm{JH}$ : Well, I also wrote Popular Reality (1996), which I intended to be a textbook for journalism studies. I personally think it is one of my better books but I made a category error, which is that journalism academics don't read books ... they read journals; and they don't do theory. In that book I wrote a history of journalism and presented a theoretically informed approach to journalism - what is journalism for the society? How do you become a journalist? I argued that journalism is the textual system of modernity.

SO: Still sits with your initial interest in audience as co-creators.

$\mathrm{JH}:$ Yes.

SO: Did you do any cultural industries work while in Cardiff? Perhaps when supervising Daniel Meadows?

JH: The photojournalist Daniel Meadows was one of my staff, a colleague. There was a very strong move in the university to get the qualifications of the staff up to scratch, and I was most interested in that because Murdoch had had a very high proportion of PhDs, around 75\%. Cardiff wasn't like that at all, with tutors in film, media, typing \& shorthand; they just weren't traditional academics. However, there was a lot of pressure on these people to get PhDs and I felt very strongly that it was possible to be a practitioner and write critically and reflectively on your approach. So I encouraged 
people to do what they were good at. I was famous at Edith Cowan for doing that. They did great teaching but where was the book? Come one, get on with it, we need to hear it. Robyn Quin had been really pivotal in getting Media Studies into the school curriculum in Western Australia. I thought it was decades ahead of what was being done elsewhere but she'd never thought if writing it down and saying "here, that's my PhD" and so, again, I was encouraging her to do that. I was very keen to bring up practice as a theoretical enterprise. Not by inserting theory here and there, but by asking people to reflect on their own practice and that was their scholarship. I wanted Daniel to get a PhD and that was the way he could do it. I benefitted from that too as we needed to get our metrics up in the department, so I put in for a Higher Doctorate and I got it [laughs]. So I have two doctorates now ... a PhD and a D.Litt.

SO: Congratulations. So you did start working with cultural and creative practice there?

$\mathrm{JH}$ : Yes, but not in terms of creative industries because we didn't have the range of disciplines. What we should have done is combine with the Welsh College of Music and Drama and I wish we had but the institutional arrangements didn't allow for it.

SO: What made you leave Wales?

JH: Family. I loved it there and I thought I would be there forever. I have complete immersion in Welshness without being of it. But a job came up in Australia and I got it: Dean of Arts at Queensland University of Technology.

\section{SO: Was that a good move?}

$\mathrm{JH}$ : It turned into a very important one for me. I was brought in to do something about Arts at QUT. This was 2000 and I was given a 5-year appointment. It had been QIT - Queensland Institute of Technology - and the guy who was the last director of QIT became the first Vice-Chancellor of QUT, Dennis Gibson. He had learned from his daughter, Leanne Gibson, that there was such a thing as the creative industries, the term was already in use.

The Faculty of Arts was the biggest faculty in the university, across several of the amalgamated campuses, and morale was low. Within six months we had designed a Creative Industries Faculty to replace the Faculty of Arts. We sent the psychologists off to Science, tapered down Social Work, closed Humanities, can you imagine, and joined the Art and Media schools together.

\section{SO: Is that your QUT legacy: Closed Humanities?}

$\mathrm{JH}$ : So The Australian newspaper would have it. It was controversial. My argument is that the Humanities are being taught everywhere, not just in a School of Humanities. The Courier Mail sent a reporter to come in and do a profile of me. I thought they would let me say that I was trying to unite the Arts with economy and enterprise, and isn't that a good thing? But they weren't having any of that. In fact, the editor of the Courier Mail, who went on to be editor of the Australian, announced that the relativists and postmodernists had taken over Journalism and so he we would never take cadets from QUT again, but they did. 
JH: For a while. I had a five year appointment as Dean, which I completed. I had put in for two grants for 2005: Federation Fellow and the ARC Centre of Excellence for Creative Industries and Innovation $(\mathrm{CCl})$, for which I would be the co-founder and research director. Amazingly, we won them both.

SO: That is when you grew your creative industries team?

JH: Yes, we were a powerhouse (See: Hartley, 2005).

SO: How do you draw a line from Cardiff and cultural studies to creative industries at QUT with the focus on arts, industry and innovation and so on?

$\mathrm{JH}$ : Well, I sort of think it is all connected. One thing I would note is that by the end of the 1990s the energy for cultural studies as an intellectual powerhouse was over. Partly because of the assault on it from American individualism and right wing politics, which confined it rather than defeated it, just kept it out of the way and made it hard to do. I wanted to bring the kind of insights that cultural studies, cultural history, communication, journalism and media studies could bring to contemporary life around to the front of the university and not confine it to a begging bowl at the back. It was as simple as that. I had an ambition for institutional reform - the disciplinary apparatus. I thought it was all unfit for purpose. Still is actually ... but that's another story.

We had various schools of thought, some insurrectionary, some socialist, some theoretical, but we missed the creative arts, and yet television comes out of that tradition. It comes out of being able to do practical things, with narrative, music, scene design and so on. So the most important people were completely missing from the kind of cultural studies' conversation that I was interested in. This matched my interest in filmmaking as a 'no budget' enterprise - using Super 8 and so on and. This went back to my time in Cardiff when I worked at Chapter Arts Centre as well as the Poly of Wales. I had a very strong interest in alternative models for filmmaking.

\section{SO: Is creative industries elitist?}

$\mathrm{JH}$ : No. Why would you think that? If so, that's a shame. What we were really doing was working with arts professionals who loved their craft but they needed a future, a way to understand the business and make their own way through that. As in: what does a dancer do when their knees give out? Also we needed to provide a way for the Arts to be developed in Brisbane as an industry, as a cultural pursuit - rather than telling people who were good to go elsewhere. We needed to develop ways to give them the tools to develop and do their craft at home. So the culture, rather than being elitist, was "do it yourself" - much like the Super 8 filmmaking I referred to.

The thing also about creative industries at QUT was that this was right in the middle of the [Amanda] Vanstone cuts. I got to QUT when the Howard government took $12 \%$ off the university budgets. So, what's going to go? The Humanities. We needed to find a story to tell that would interest creatives, parents, politicians and business. And we did it, very ambitiously. We got business leaders to come and talk to us, politicians to come and listen to us, one of the first was the Premier of QLD, Peter Beatty. In a provincial city like Brisbane it was a case of do it yourself or not at all. Otherwise, you'd be training your graduates to leave town. But it had to be done properly and we had to build a community to do it, which was difficult in the context of the Howard Government. 
$\mathrm{JH}$ : As the first creative industries faculty in the world we had no role-models or even peers. Our intellectual community saw it as sort of New Labour or neoliberal (boo-words in cultural studies). It wasn't. We carried because and the moment when I thought we were catching onto an explanatory framework for the economics of creativity was when I started talking to economists, whose stance was so different from the Arts. In fact, the most productive conversations were with the least sympathetic economists, especially the evolutionary economists who were at that time an influential group at the University of Queensland. It seemed to me that evolutionary economics had explanatory power in relation to the way creativity works in the economic environment of modernity.

\section{SO: So these thoughts coincided with your Federation Fellowship? Can you define evolutionary economics?}

$\mathrm{JH}$ : Yes, Jason Potts was hired by Stuart Cunningham, who was director of the ARC Centre of Excellence for Creative Industries and Innovation. He got in touch with the School of Economics at UQ and asked Jason to help develop the economics of creativity. Jason's view is that economics is not based on scarcity or money or creating wealth, but simply on the growth of knowledge. With us, he thought he would fall in amongst the Marxists and be savaged. But, actually, we learned from each other and bonded through mutual respect for Karl Popper - who understood the evolution of the economy as an autonomous process which had its own rules and possibilities and its own history. That's really where we [Hartley and Potts] joined forces. I have always been interested in the growth of knowledge. I think the growth of knowledge is as important to culture as anything else and it's the fact that there are different kinds of knowledge - one of which is creative rather than scientific or philosophical - that brought us together.

\section{SO: Is this the moment that you moved from cultural studies to cultural science?}

$\mathrm{JH}$ : I moved to cultural science partly as a very deliberate attempt to acknowledge that governments listen to scientists but not to culturalists. If you want to change society, then you have to be able to talk to them, and have a story that's compelling enough for them to listen. 'Cultural science' is not an exact science but a bioscience.

\section{SO: How do you define cultural science?}

$\mathrm{JH}$ : The question really is, what is culture? Of course there are multiple answers to that already, but most of them reduce culture to something connected with their discipline: for social scientists it's behaviour; for literary theorists it's text, etc. From an evolutionary perspective, culture must be related to language as a system and signalling as a process.

The most important human invention is language, the constitutional foundation of any culture. Language is not just behaviour, nor just a tool or technology. Language is not just verbal utterance. It is also the entire 'universe' of human signification, the means by which we apprehend and shape the world and each other. The general term for signification is 'semiosis' - 'a process in which something functions as a sign to an organism' (see the Merriam Webster for that definition) - a definition that leaves room for communication to extend well beyond humans, although language is known only among that genus. Making sense of language (as a general phenomenon) needs an interdisciplinary approach, to integrate three levels of signification: micro-level textual aspects of communication selves; meso-level social and media institutions - stories; and macro-level global systems, both human and natural - statistics. 
SO: Are you referring to Bronfenbrenner's ecological framework for human development (1979)? How do you understand these groups?

$\mathrm{JH}$ : To understand groups and to find an adequate model of the multi-level and dynamic processes involved in cultural semiosis I have turned to the cultural semiotics of Yuri Lotman (1990; 2009), who developed an evolutionary and complex-systems approach to language and culture, summed up in his concept of a planetary 'semiosphere' - the domain of signs - on the model of the biosphere. As the enabling or constitutional space of any sign system, the semiosphere is both pan-human and constantly changing, such that the majority of languages that have ever existed are extinct, but still humans organise themselves into groups through the affordances of language. Signs and their particular uses belong not to individual creators but to subpopulations, which in cultural science are called 'demes', borrowing that term from 'subpopulations' in biosciences and from political science's 'demos' (Hartley and Potts, 2014), which means that culture is, literally, 'pan-demic'.

With respect to groups, the basic propositions of cultural science are: culture makes groups (not things); groups (not individuals) make knowledge; knowledge is created (and contested) in the zone of uncertainty between groups; groups (classes) are organised around the means of their own mediation (specific languages or argots in speech; specific technological platforms in writing and representation).

Although we're used to thinking of language-communities in ethnoterritorial and tribal terms, a culture-made group or 'deme' can equally be organised around demographics (gender, sexuality, age), occupations (corporate culture, specialist skills and knowledge disciplines), or affiliations (fans, taste cultures).

Culture-made groups are organised around the means of their own mediation:

- Modern nations: the press (citizens) (Anderson, 1991);

o Whence, sciences (disciplines), public affairs (journalism), private affairs (the novel).

- Classes: industrial classes are organised around the workplace; postindustrial classes are organised around communication technologies;

o Whence, broadcasting (the nation), social media (the species).

- Popular culture: links groups by affiliation not condition (audiences);

o Whence, fans (sport, music and screen media), influencers and activists (social media).

SO: How do these groups make knowledge in a cultural science paradigm?

$\mathrm{JH}$ : In each of these historically unfolding group-making cultures and technologies, the salient process is the generation and growth of knowledge - internally, to bind the group; externally to contest or control other groups. Thus the growth of knowledge as a whole is itself an evolutionary process, independent of any one group or culture. It occurs across different groups, by cooperation (trade, translation and appropriation), or by conflict, all the way up to warfare and conquest (Ronfeldt and Arquilla, 2020). Thus, demes are strongly marked by 'we' and 'they' difference, which they project onto the world, populating space and time with gods like 'us' and monsters like 'them'.

Given the multi-level structure of signifying systems (micro-meso-macro, Dopfer et al., 2004), it follows that knowledge-making groups are found at each level - micro-level: knowledge'clubs'(Hartley et al., 2019); meso-level: knowledge institutions (Hartley, Ibrus and Ojamaa, 2021); and macro-level: 'demes' (Hartley and Potts, 2014).

Cultural science models cultures as internally cooperative (seeing 'our' semiotic universe as universal), and as externally adversarial (seeing 'their' culture and knowledge as both false and a threat). Competition and conflict among groups stimulates new knowledge, which means that while difference is suspicious it is also vital for renewal and adaptation to change. Knowledge is dynamic. 
Innovation is the process of uptake of new ideas (knowledge, know-how) among populations. As a result, knowledge is reflexive, interested in its own processes as well as in the world it seeks to describe. The same goes for demes, which are strongly marked by what Lotman calls 'auto-communication' or self-description, which serves both to confirm and to update a deme's meaning system.

Social historians have applied these perspectives to early civilisations (Turchin, 2007) and to modern social antagonisms (Malešević, 2017). Their findings support the idea that inter-demic competition drives innovation, but it also drives increasing social and organisational complexity.

Only complex civilisations can make war and, historically, all civilisations must make war, if they are to avoid being overwhelmed or absorbed by others. Consequently, civilisations have evolved through increasing scale and organisational complexity, in order to protect themselves from external threat, especially from superior technologies such as lethal weapons. Thus, from the Neolithic to now, states and empires have evolved institutions ,- ideology (macro), bureaucracy (meso), and 'microsolidarity' (micro) - to defend themselves against external threat, resulting in growth not only of knowledge but also of systemic violence (Malešević, 2017), as each successive empire absorbs the knowledge systems of its predecessors and generates new knowledge-systems of its own.

SO: You referred to Benedict Anderson (beware Jason!) before, once the community is established, how does the "imagining" operate?

$\mathrm{JH}$ : In this context, where'we' groups (demes) are both elaborately organised and fearful of outsiders, culture has evolved various mechanisms for imagining new horizons of possibility and rehearsing new modes of organisation to deal with threats. Chief among these are fictions. The term 'fiction' has recently undergone a massive rethink. Historian Yuval Harari (2014) has proposed that it is the most distinctive feature that characterises humans. It underlies both their organisational and their technological capabilities. Harari refers to structures that do not exist in nature but nevertheless set the rules by which humans live and act. They include nations, corporations, gods, money and law none of these are part of the non-human biosphere or geosphere. Fictions, then, define humanity, and culture is their generative mechanism. They are institutions of language.

Put together uncertain facts with alternate universes and you have science fiction. Science fiction is a genre of auto-communication, allowing a culture to rehearse or play with the implications of its own potential futures (at much lower cost than actual experiments). Corporate consultancy firms like PwC (PriceWaterhouse Coopers) have already sought to exploit this (PwC, 2017). Especially in the sphere of artificial intelligence, machine learning, robotics and digital connectedness, science fiction has proven to be a valuable resource for scanning the horizons of possibility for new threats to 'us', and for rehearsing new rules in the imagination, before committing valuable resources in fact.

For cultural science, science fiction is a natural laboratory for imagining new knowledge groups. What is special about science fiction is that it can imagine humanity as a single, species-wide deme, and follow through with the consequences of that (usually to face an external, alien threat). Science fiction is way ahead of science fact in integrating humanity as a single knowledge-group.

SO: Explain this a little more for me? How does that take us back to cultural science?

$\mathrm{JH}$ : In cultural semiotics, the condition of existence for truth is not 'the real' but lying, because we apprehend the real only through the affordances of language and culture. That which is true or 'real' (nature) must become 'sign' (culture) in order for language to signify at all. As the great semiotician Umberto Eco put it: 'If something cannot be used to tell a lie, conversely it cannot be used to tell the truth: it cannot in fact be used "to tell" at all' (Eco, 1976: 7). The relationship of sign to sign cannot be decided by reference to nature; only to the rules and laws of the sign system. The self, other, real, 
truth are all language games (Wittgenstein, 1953: 23; Peters, 2020).

Language enables deceit, duplicity and hidden intentions, but also descriptions of systems outside itself, other selves or the external world. It's not that you can't trust communication; it's that you can't trust reality, because it's a human-made 'fiction'.

Semiosis is the ocean in which all humans swim, and make up their world as they go along. But it's also real. In line with the new science of biosemiotics (Emmeche, and Kull, 2011), Susan Petrilli and Augusto Ponzio locate semiosis in the Earth-system, not just in human culture but in the sphere of life, which they dub the semiobiosphere: "Global semiotics underlines the fact that the semiosphere is part of a far broader sphere, the semiobiosphere, a sign network human beings have never left, and to the extent that they are living beings, never will" (Petrilli and Ponzio, 2007: 31).

Life intersects with inert matter, but they're not the same. When we're dead our inert matter is recycled, one way or another, but our life is not.

Over epochal time, life contributes matter to 'terraforming' this planet with soil and sedimentary rocks, like chalk, limestone, coal and other'fossil'fuels, breathable atmosphere and an equable climate. Life as a whole has influenced, sustained and regulated the processes necessary for its survival (e.g. feeding, predation, reproduction) over a 4+ billion-year 'lifespan', even while each life form evolves and acts blindly in relation to the overall ecosystem.

Unfortunately, communication, culture, language and the semiosphere (Lotman, 1990) have not been integrated well, or at all, into scientific models of culture, leaving this entire domain outside of scientific notions of the real (Mesoudi and Thornton, 2018; Mesoudi, et al., 2006). Thereby, the evolutionary bio-sciences deprive themselves of a fundamental component of their model of culture's dynamics - semiosis.

Now, however, as Petrilli and Ponzio point out,'communication and production have come together' through technology and automation, 'presenting a phenomenon that is altogether new, calling for analysis from two interconnected perspectives: the economic and the semiotic' (2007: 89).

A fully theorised synthesis of humanities and biosciences is long overdue - it was first proposed by Julian Huxley in 1955. Where 'communication and production have come together', the constitution of imaginary structures (story) needs to be conjoined with measurement of empirical behaviour (science), in order to understand both economic and technological change. Through creative knowledge practices and collective scholarly action, I'm hoping that we can imagine such a critical venture into reality.

That is the project of cultural science (Hartley and Potts, 2014; Hartley, 2020; Hartley, Ibrus and Ojamaa, 2021, Hartley and Herrmann-Pillath, 2021; and Cultural Science Journal).

SO: Thank you. So this really is moving on from cultural studies, not positing cultural science as a branch of cultural studies?

$\mathrm{JH}$ : Not exactly. Throughout this process I was strongly motivated by the idea that there was a cultural science at the bottom of cultural studies and it had got lost. Cultural Studies had become adversarial, ideological and insurrectionary. That is great but it is only an avant-garde stance. In addition, you have to understand systems, or you will never understand how things work: you can't just grab the levers of power and just make things better. You need to know how systems work.

\section{SO: But isn't that Foucauldian? Doesn't that take you back?}

JH: Yes, it does! I don't think I ever left it and that's kind of what I am trying to say. It's not only Foucault but also Lotmanian - and that's why Lotman was so important to me. He was a through-andthrough literary theorist and scholar, but he is also interested in cybernetic feedback and in how the 
different systems relate to each other. I felt that here was an opportunity for creativity, culture and knowledge to be systematised into a model. That wasn't explored sufficiently in the cultural studies I was interested in - and still am interested in.

SO: I keep sticking on evolution, talk a little more about it.

$\mathrm{JH}$ : Evolution was a problem for cultural studies and the radical humanities because of social Darwinism, which is an absurd and ludicrous bit of fake news. There is the eugenic hangover, but that is not my thing, even though I have used Julian Huxley for an attempt to understand how you might have a biological view of culture, which he published in 1955 (without any eugenic argument). I never held any interest in eugenics and I don't think it is evolution - evolution is not interested in individual species. I am a 'strong' evolutionist, I do not believe in progress, I do not believe in the evolution of the human race as they call it.

SO: But the liberal dilemma - simplified - is also the justification of how can I study these communities which I have identified as variously disadvantaged and still exist with my own privilege recognising that difference. That's why there is a dilemma around evolution because if you are a good liberal academic and you live by what you are writing then you are always in that complex of using your privilege to reinforce what and who you are writing about. So are you always existing in colonial structures and so on...

$\mathrm{JH}$ : I don't have any problem with that, I think it is the case. I am a product of those colonial structures as much as anything else. You do take an interest in those who live disadvantaged lives for structural reasons. In Australia that is First Nations people first and foremost. When I first came to Australia, many of the people who took up their cause in relation to media were foreigners like me and the Canadian Steve Mickler. To give you an Idea of what I'm talking about: in those days there was a professional directory called Margaret Gee's Media Guide, which listed journalists by specialism. It listed pages of football reporters but not a single Indigenous correspondent. My first ARC grant was on the treatment of Aboriginal people by the Australian press, which became a book: The Indigenous Public Sphere, co-authored with the Scot Alan McKee (OUP 2000).

And so I get it, but I think identity politics by themselves tend to leave things unfinished. They can be on class, then gender, then race, then on sexuality, and so on, but this is what I call the problem of the ampersand - when there are so many identities to specify that you miss what makes these things connect.

And, you know, I am trying to answer that question: if you need system change, how do you do system change. The people asking that most compellingly are 15 year-olds in Sweden.

SO: Greta. But that is because we do not know how to do system change.

$\mathrm{JH}:$ Yes.

SO: So cultural science was the project for your Federation Fellowship?

$\mathrm{JH}:$ Yes, in $2008 \mathrm{I}$ had funding to call together a research symposium of people who might be interested in cultural science. From the CCl, Jason Potts was there, Lucy Montgomery was a PhD student along with other PhDs, and Ellie Rennie was there as a post-doc. This symposium was pivotal and where we launched the Cultural Science Journal. A group of evolutionary biologists from Durham University volunteered to hold the next symposium in 2010, and so the 'discipline' was launched and the circle widened out beyond cultural studies. 
$\mathrm{JH}$ : I was appointed as director of the Centre for Culture and Technology, and Professor of Cultural Science.

SO: Did you bring Creative Industries with you to Curtin?

JH: Yes, through the CCI. We had put in for further ARC funding from 2010 and Cultural Science was one of the six programs supported by the $\mathrm{CCl}$ in its second phase.

The then Vice-Chancellor of Curtin was interested in installing 'creativity' as one of four research 'pillars'for the whole university. A series of meetings and discussions was held, but no agreement was reached within the School, Faculty or University on what was meant by that term, and the proposal faded.

I wanted to contribute a 'creative economy' dimension to the development plan of Greater Curtin. But the idea of an urban village or creative precinct was not welcome: 'Greater' Curtin was firmly understood to be a real-estate/technology venture, and my proposal rebuffed at PVC/DVC level (see: Curtin, 2021).

I made a presentation on the 'creative city' / 'creative economy' concept to a joint meeting of the WA State Government's Transport and Planning departments. It was well received by the bureaucrats (more than 50 came to the presentation) in a lively Q\&A after my presentation, but failed to gain traction with then State Government. Similarly, corporate-supported arts ventures (e.g. FORM) were not oriented to creative-economy policy development.

In contrast, I had made similar presentations to ministerial-level meetings in China, at the CCP's China Executive Leadership Academy Pudong (CELAP), and also to individual cities and provincial authorities; in Indonesia, at the invitation of the Minister for Trade Mari Pangestu; and at the Thailand International Creative Economy Forum (TICEF), in the presence of the then Prime Minister. Each of these countries established a vigorous creative industries / creative economy policy, and they all actively sought input from foreign experts, especially WIPO (the UN's World Intellectual Property Organisation), the British Council, and think-tanks such as Demos, BOP Consulting (John Howkins), as well as the $\mathrm{CCl}$. The world was abuzz with creative industries.

Similarly, at the CCI's home base in Queensland, the State Government partnered with CCI and QUT in policy development for their 'smart state' initiatives, and - through the Australian Academy of Humanities - the CCl lobbied Canberra on creative economy policy.

Only in WA was there no response, at university, state or corporate level.

\section{SO: That's disappointing. Did CCAT start with you? Was cultural science in CCAT?}

JH: CCAT was proposed and established in 2011 by Niall Lucy, with support from head of school Steve Mickler. Niall had been a colleague of mine at Murdoch University in the 1980s-90s. In the 2010 Excellence in Research Assessment exercise (ERA), cultural studies was the school's top-ranking discipline area. Steve Mickler and Niall wanted to link cultural studies with research in digital media technologies.

Cultural Science became a program of CCAT, and established Curtin as a partner institution or 'node' of the CCI. The CCl's own biannual research symposium was held in Perth for the first time in December 2012. Two journals of which I was editor, the International Journal of Cultural Studies and Cultural Science Journal, were hosted at CCAT.

Niall Lucy died in June 2014, which changed the nature of CCAT from then on. I relinquished the directorship after three years, and transferred from the Faculty Research Office to the School, where I was allocated to Internet Studies, remaining there until 2019, when I'left' Curtin. 
SO: What is the passage of cultural science at Curtin - how did it unfold? Who came on board as a cultural scientist?

JH: Cultural science remained a research program in CCAT until 2019, when it was superseded by the Curtin Open Knowledge Initiative (https://openknowledge.community/about-coki/), led by Lucy Montgomery and Cameron Neylon.

As well as developing the theoretical model for cultural science (largely in publications by myself and co-authors), we also sought to instantiate the approach, for example critical humanities + data analytics; and systems/evolutionary approaches to culture, across numerous projects, including research related to Indigenous knowledge, especially the Noongarpedia (see Cultural Science Journal Vol. 9, 2016), the development of a creative and knowledge economy in China, and the role of the internet and digital media in creating knowledge-communities.

At Curtin, cultural science 'unfolded'from the CCI Cultural Science program in the direction of the open knowledge agenda. Jason Potts (by then at RMIT) and I co-authored a book called Cultural Science (Bloomsbury, 2014). I completed my own contribution to that program with two further monographs: How We Use Stories and Why That Matters (Bloomsbury 2020); and On the Digital Semiosphere: Culture, Media and Science for the Anthropocene, co-authored with Indrek Ibrus, Tallinn University and Maarja Ojamaa, Tartu University (Bloomsbury 2021). As part of this research collaboration I was invited to give the Annual Juri Lotman Lecture (https://www.ffi.ut.ee/en/department-semiotics/juri-lotman-lectures) at Tartu University in 2016.

Lucy Montgomery formed a research partnership with publisher Frances Pinter (who'd founded Bloomsbury Academic), to work on a library consortium model for publishing scholarly books in the humanities, Knowledge Unlatched (reported in Cultural Science Journal 7:2). A collaboration with researchers Jason Potts and Ellie Rennie at RMIT and with Cameron Neylon (of PLOS, subsequently appointed to Curtin), resulted in several articles on scholarly publishing and on public intellectuals. In 2018-19, Curtin seed-funded the Curtin Open Knowledge Initiative (COKI) with co-leaders Montgomery and Neylon; now externally funded by Mellon and other foundations.

We won funding from Tencent Ltd. (China) for research collaboration, and I made a keynote presentation at the Culture + Tech International Forum held at the Palace Museum, Beijing, in 2017. 'What Hope for Open Knowledge?' was published in Cultural Science Journal (10:1).

CCAT hosted an International Research Symposium on Open Literacy, funded by Tencent, in 2019, also published in Cultural Science Journal (2019-20). Lucy Montgomery is lead author (of 13) of Open Knowledge Institutions, published (Open Access) by MIT Press in 2021.

I was appointed a visiting professor at the LSE for 2020-21, and made several contributions on the theme of children and media from a cultural-science perspective (see: Hartley, 2020).

Beyond Curtin, an early and continuing collaborator in the cultural science adventure is Carsten Herrmann-Pillath. He led the East-West Centre for Business Studies and Cultural Science at Frankfurt School of Finance and Management, Germany; and is now at the Max Weber Centre for Advanced Cultural and Social Studies at Erfurt University. His book, The Economics Of Identity And Creativity: A Cultural Science Approach, was published by UQP in Australia and Transaction/Routledge internationally. Carsten and I have collaborated on numerous projects since then, including a joint paper on the semiotics of the 'technosphere' for KODIKAS Journal, and for a special issue of RS/SI Journal on semiotics and economics. Carsten has published in Cultural Science Journal (3:1 and 10:1) and in the International Journal of Cultural Studies (13:4).

The Centre of Excellence in Media Innovation and Digital Culture (MEDIT) at Tallinn University, Estonia, has been a continuing collaborator with the cultural science project (embed: http://medit. tlu.ee/news/medit-seminar-cultural-science). Profs Indrek Ibrus and Max Schich are now the editorsin-chief of Cultural Science Journal, published by Sciendo (http://medit.tlu.ee/news/cfp-re-introduc- 
tions-to-cultural-science). Indrek and his colleague Maarja Ojamaa of Tartu University co-authored On the Digital Semiosphere with me, and more recently we published a paper in the Nordic Journal of Media Studies (Hartley, Ibrus, Ojamaa, 2021).

SO: What is the external perception of Cultural Science?

JH: Cultural Science (Hartley \& Potts) has been reviewed by Jonathan Gray (2016); Mark Gibson (2016). Also informally at https://on-writering.blogspot.com/2021/01/in-praise-of-cultural-science-hartley. html.

On the Digital Semiosphere has been reviewed by Carlos Scolari (in Spanish) https://hipermediaciones.com/2021/10/17/la-semiosfera-digital/.

SO: What is the future for Cultural Science Journal? What should the journal do?

$\mathrm{JH}:$ I think there is a huge future. I think we should try to conjoin history with big data and analytics, history-of-art type data.

SO: So is that what the Curtin Open Knowledge Initiative are doing?

JH: Yes, absolutely.

SO: This is a long way away from Stuart Hall style cultural studies, with a primary focus on class?

JH: Yes, I agree.

SO: As a final question ... what is the role of the Cultural Science Journal editor?

$\mathrm{JH}$ : There are journals of tendency, which produce the field and define it and populate it, and journals of record, which are trying to record and identify the work being done in the field. We haven't established the field yet, so it must be a journal of tendency, we must try and develop the field. It couldn't be harder as if you publish in your own journal you are regarded as a vanity publisher, if there is a circle of citation - so all the same people - it just looks awful. So it is really hard to establish a field and that is made worse because it is an interdisciplinary field. You have to have very well established scholars coming from different fields and perspectives and writing cultural science without being cultural scientists. I do think the journal needs to take that seriously and start to populate a field rather than simply record pragmatic pieces. Follow the energy to do so - not status, discipline, field - but people who are writing cultural science. Follow the energy is what a journal should do.

SO: Good luck Indrek!

$\mathrm{JH}:$ Yes, indeed, he knows what he is doing; and so does co-editor Max Schich. 


\section{References}

Anderson, B. (1991) Imagined Communities. London: Verso.

Bronfenbrenner, U. (1979). The Ecology of Human Development: Experiments by Nature and Design. Cambridge, Massachusetts: Harvard University Press.

Curtin (2021) https://techparkwa.com.au/bentley-curtin-specialist-activity-centre-plan-technology-park/; and https://properties.curtin.edu.au/news/160428-stageone.cfm.

Eco, U. (1976) A Theory of Semiotics. Bloomington, IN: Indiana University Press.

Emmeche, C. and Kull, K. (eds) (2011) Towards a Semiotic Biology: Life Is the Action of Signs. London: Imperial College Press.

Fiske, J. and Hartley, J. (1978) Reading Television, London: Methuen.

Fiske, J.; Hodge, B. (R. I. V. ) and Turner, G. (1987). Myths of Oz: Reading Australian Popular Culture. U.S.A: Allen and Unwin.

Frow, J. (1995) Cultural studies and cultural value, Oxford: Clarendon Press.

Gibson, M. (2016) John Hartley and Jason Potts, Cultural science - a natural history of stories, demes, knowledge and innovation, Communication Research and Practice, 2:3, 432-434, DOI: doi.org/10. 1080/22041451.2016.1224153.

Gray J. (2016). Book review: John Hartley and Jason Potts, Cultural science: A natural history of stories, demes, knowledge and innovation. Communication and the Public. 1(3):386-388. DOI: doi. org/10.1177/2057047316667519.

Grossberg, L. (1997). Bringing it all back home: essays on cultural studies. Durham, North Carolina: Duke University Press.

Harari, YN. (2014). Sapiens: A Brief History of Humankind. London: Harvill Secker.

Hartley, J. (2020) How We Use Stories and Why That Matters. New York: Bloomsbury.

Hartley, J. and McKee, A. (2020), The Indigenous Public Sphere, London: OUP.

Hartley, J. and C. Herrmann-Pillath (2021) Towards a semiotics of the technosphere. KODIKAS/CODE: An International Journal of Semiotics, 41(3-4), 175-96.

Hartley, J. (2005), Creative industries, J. Hartley ed. London: Wiley-Blackwell.

Hartley, J.; Ibrus, I. and Ojamaa, M. (2021) On the Digital Semiosphere. New York: Bloomsbury.

Hartley, J.; Ibrus, I. and Ojamaa, M. (2021). "Emergent self-mediating classes in the digital semiosphere: Covid-19 conspiracies and the climate justice movement". Nordic Journal of Media Studies, 3(1), 118-140. DOl: doi.org/10.2478/njms-2021-0007

Hartley, J. and Potts, J. (2014) Cultural Science. London: Bloomsbury.

Hartley, J.; Potts, J.; Montgomery, M.; Rennie, E. and Neylon, C. (2019) 'Do we need to move from communication technology to user community? A new economic model of the journal as a club'. Learned Publishing, 32, 27-35.

Hartley, J. (2020), "Children of Media - World-builders, Culture, deme formation and children's class consciousness in the global-digital semiosphere." Media@LSE Working Paper Series \#65; https:// blogs.Ise.ac.uk/parenting4digitalfuture/2021/03/17/children-of-media/; and https://core-evidence.eu/core-theories-vlog-john-hartley/.

Herrmann-Pillath, C. (2010) The Economics Of Identity And Creativity: A Cultural Science Approach. UQP and Transaction/Routledge.

Hodge, B. (2017), Social Semiotics for a Complex World: Analysing Language and Social Meaning, Polity Press.

Lotman, Y. (1990) Universe of the Mind. Bloomington IN: Indiana UP.

Lotman, J. (2009) Culture and Explosion. Berlin, Mouton de Gruyter.

Lee, RE. (2010) Knowledge Matters: The structure of knowledge and the crisis of the modern world system. St. Lucia, Qld: University of Queensland Press [US: Transaction Publishers, now Routledge]. 
Malešević, S. (2017) The Rise of Organised Brutality: A Historical Sociology of Violence. Cambridge: Cambridge UP.

Manning, P. (2020) A History of Humanity: The Evolution of the Human System. Cambridge: Cambridge UP.

Megarrity, L. (2018), "Geoffrey Bolton and the Writing of Australian History", Australian Policy and History. https://aph.org.au/2018/12/geoffrey-bolton-and-the-writing-of-australian-history/.

Mesoudi, A. and Thornton, A. (2018) What is cumulative cultural evolution? Proceedings of the Royal Society B, 285: 20180712. DOl: doi.org/10.1098/rspb.2018.0712.

Mesoudi, A.; Whiten, A. and Laland, K. (2006) Towards a unified science of cultural evolution. Behavioral and Brain Sciences, 29, 329-83. DOl: doi.org/10.1017/S0140525X06009083.

O'Toole, M. (1990) A systemic-functional semiotics of art. Semiotica, 82 (3/4). pp. 185-209.

Quin, R. and McMahon, B. 2007. "The what, why and how we know of media education." In Rethinking Media Education First., 217-237 Cresskill, NJ 07626: Hampton Press.

Ronfeldt, R. and Arquilla, J. (2020) Whose Story Wins: Rise of the Noosphere, Noopolitik, and Information-Age Statecraft. Santa Monica CA: RAND Corporation: https://www.rand.org/content/ dam/rand/pubs/perspectives/PEA200/PEA237-1/RAND_PEA237-1.pdf.

Ruthrof, H. (1997) Semantics and the body: Meaning from Frege to the postmodern. University of Toronto Press, Toronto, Canada.

Turchin, P. (2007) War and Peace and War. The Rise and Fall of Empires. New York: Plume/Penguin.

Turner, G. (1990) British Cultural Studies: An Introduction, Allen and Unwin.

Wittgenstein, L. (1953). Philosophical Investigations. Oxford: Blackwell. 